Ks. Jan W. ŻELAZNY

(Kraków, PAT)

\title{
ŚW. JAN CHRYZOSTOM W NAUCZANIU JANA PAWEA II
}

Moje wystąpienie chciałbym podzielić na dwie części: w pierwszej, korzystając z okazji, chciałbym zaprezentować zainteresowanie Księdza kardynała Karola Wojtyły patrystyką w Polsce; w drugiej, zgodnie z zapowiedzianym tematem, skupię się nad wykorzystaniem myśli św. Jana Chryzostoma w nauczaniu papieskim.

\section{KARDYNAŁ KAROL WOJTYŁA WOBEC STUDIUM OJCÓW KOŚCIOŁA}

Pod koniec lat sześćdziesiątych XX wieku kardynał Wojtyła został przewodniczącym Komisji d/s Nauki przy Konferencji Episkopatu Polski. Od początku w kręgu jego zainteresowań pojawiło się studium Ojców Kościoła. Było to, zdaniem relacjonującego opisane wydarzenia ks. prof. dr hab. Edwarda Stańka, spowodowane kilkoma przesłankami. Od chwili podjęcia pracy na Katolickim Uniwersytecie Lubelskim łączyła go przyjaźń z panią profesor Leokadią Małunowiczówną. To, nad czym pracowała, co ją samą inspirowało $\mathrm{i}$ interesowało, poprzez rozmowy, poprzez sugestie, trafiało do Wojtyły. Jedną z jego cech, i to fenomenalną, była zdolność do słuchania. On umiał słuchać, on chciał wysłuchać drugiego, on chciał tak się uczyć. Osobisty kontakt z wybitną znawczynią literatury starochrześcijańskiej pozwalał mu na zapoznanie się z bogactwem myśli Ojców Kościoła. Kardynał Karol Wojtyła zawsze podkreślał, jak wiele można skorzystać ze spotkania z tymi, którzy są świadkami tradycji Kościoła. Wydaje się, że to właśnie pani prof. dr hab. Leokadia Małunowiczówna, badaczka i tłumaczka dzieł Ojców Kościoła, w dużym stopniu wpływała nie tylko na jego zainteresowania patrystyką, ale także na to, po jakie dzieła Ojców Kościoła sięgał przyszły papież.

Ale nie można zainteresowań Wojtyły związanych z patrologią sprowadzić tylko do kwestii osobistych znajomości. Świadomość wagi świadectwa Ojców w uprawianiu teologii w Kościele miała jeszcze inny wymiar. Teologię można 
uprawiać korzystając z różnych metod. W tym czasie, jak i zresztą po dziś dzień, najbardziej rozpowszechniona była metoda studium spekulatywnego, zmieniały się tylko przesłanki jak i pytania stawiane przez uczonych. Tymczasem Ojcowie zmuszają do podjęcia refleksji teologicznej przy użyciu metody historycznej: ich refleksja nie jest tylko spekulacją. To jest zawsze teologia $w$ drodze, teologia funkcjonalna, teologia pastoralna. Odnowa zaproponowana na Soborze Watykańskim II miała uczulić cały Kościół na ten wymiar pastoralny, duszpasterski. Refleksja Ojców Kościoła, to refleksja w większości duszpasterzy, ludzi związanych z życiem i funkcjonowaniem wspólnoty wierzących, ludzi, którym problemy i pytania dnia codziennego chrześcijan nie były obce. To uaktualnia nie tylko sposób przekazu i argumentacji, ale jednocześnie sprawia, że patrologia ukazuje teologię uwikłaną w praktykę życia, a nie na jego marginesie. Jest dyscypliną odpowiadającą na pytania ludzi, a nie stawiającą samej sobie zagadnienia do rozwiązania. Myśl Ojców to nie jest teologia sal uniwersyteckich, to teologia głoszona z pasją z ambon, teologia biskupów duszpasterzy. Tymczasem przedstawicieli tej metody historycznej, zawsze zaangażowanej duszpastersko, nigdy nie było za dużo w świecie nauki. Tak było w XX wieku, tak jest i teraz.

Sam Karol Wojtyła, jako filozof i etyk, był przedstawicielem teologii spekulatywnej. Jednak ówczesnego Biskupa Krakowskiego cechowała otwartość na inne sposoby spotkania z tajemnicą Boga, jak i uprawiania teologii. Stąd, wysyłając na studia ks. Edwarda Stańka i kierując go do ks. prof. dr hab. Mariana Michalskiego, wprost oświadczył delegowanemu kapłanowi, że ma świadomość, iż uczniów I. Różyckiego (ks. Staniek uczęszczał na seminarium naukowe pod kierunkiem krakowskiego dogmatyka prof. dr hab. Ignacego Różyckiego) zawsze będzie sporo, a jest wymogiem chwili, aby w krakowskim ośrodku był ktoś reprezentujący sobą inną metodę uprawiania teologii, ktoś, kto przedłużyłby doświadczenie teologii uprawianej metodą historyczną, reprezentowaną przez ks. Mariana Michalskiego. ,Jest potrzebny ktoś, kto przejmie metodę historyczną i przekaże ją następnym pokoleniom" - miał powiedzieć Kardynał do ks. Edwarda Stańka skierowując go na studia; przez cały okres ich trwania interesował się ich przebiegiem, wracając do tego.

Tym można też tłumaczyć jego inspirującą rolę w zorganizowaniu pierwszych spotkań Międzywydziałowego Zakładu Badań nad Antykiem Chrześcijańskim KUL i Sekcji Patrystycznej przy Komisji d/s Nauki przy Konferencji Episkopatu Polski. Jego pomoc udzielona naszemu środowisku w tamtych czasach była nie tylko symboliczna, ale i praktyczna. Kardynał Karol Wojtyła mając świadomość trudności związanych z organizowaniem spotkań badaczy antyku chrześcijańskiego i wykładowców patrologii w Polsce, dwukrotnie udostępnił swój Pałac Biskupi przy ul. Franciszkańskiej 3 na miejsce tych zjazdów (26-27 IV 1971 i 12-13 II 1974), innym razem gmach Metropolitalnego Seminarium Duchownego w Krakowie (31 V - 2 VI 1976). Sam nie tylko uczestni- 
czył w części obrad, ale w późniejszych latach zawsze prosił ks. Edwarda Stańka o relację dotyczącą kolejnych zjazdów, o prezentację tematyki, zagadnień poruszanych podczas spotkań czy wreszcie pytał o to, kto w danym ośrodku podejmuje studium Ojców Kościoła. Cieszył się z powstania Sekcji Patrystycznej (3 XI 1977) i obiecał otworzyć pierwsze jej sympozjum w Tarnowie (19-21 X 1978) na temat modlitwy starożytnych chrześcijan. Interesowały go nowości, na bieżąco śledził studia dotyczące myśli Ojców. Nie było w tym czasie, rzecz jasna, tylu publikacji, co dziś. Jego interesowało, obok studium, także troska o udostępnieniem myśli patrystycznej szerszemu gronu.

Ale teologia wykładana, to teologia żywa. To nie tylko, co jest przekazywane, ale także, kto przekazuje. Zainteresowanie ówczesnego przewodniczącego Komisji d/s Nauki KEP było także personalne. Kto pisze doktoraty, kto podejmuje studia, kto wykłada oraz sposób przekazu myśli Ojców - także to go interesowało. Na koniec trzeba wspomnieć o jeszcze jednym: pomoc praktyczna dla patrologii w środowisku krakowskim też miała swoje przełożenie w jego staraniach dotyczących uzupełnienia braków w kolekcji Migne’a w Bibliotece Seminaryjnej. Podczas wojny Niemcy spalili ok. 50 \% jej tomów, on myślał o ich skompletowaniu, ale jak to często bywa, zabrakło funduszy.

\section{JAN PAWEŁ II A NAUCZANIE ŚW. JANA CHRYZOSTOMA}

Św. Jan Chryzostom jest przywoływany przez Jana Pawła II w wystąpieniach publicznych niewiele razy. Najobszerniejszym z nich była homilia wygłoszona 13 IX 1984 roku, w liturgiczne wspomnienie św. Jana Chryzostoma, w Moncton, Front Mountain Road w Kanadzie. W encyklikach i innych dokumentach (Adhortacjach, Listach Apostolskich, orędziach, katechezach i oficjalnych przemówieniach) Jana Pawła II nasz Antiocheńczyk jest cytowany imiennie tylko jedenaście razy ${ }^{1}$. Trzeba też wspomnieć, że kilkakrotnie (12 razy) pojawia się on tylko w ich przypisach jako jeden ze świadków tradycji Kościoła ${ }^{2}$.

${ }^{1}$ Por. Encykliki: Veritatis splendor 24; Redemptoris Mater 32; Adhortacje: Familiaris consortio 16, Catechesi tradendae 12 i 29; Listy Apostolskie: Duodecimum saeculum 6; Dies Domini 71; Orędzia: Co uczynicie jemu, mnie uczynicie 5 (13 X 1991), w: Insegnamenti XXIV/2, 820; Na Wielki Post 20015 (7 I 2001), w: Insegnamenti XXIV/1, 145; Przemówienia: Podczas ceremonii powitania w Atenach 4 (4 V 2001), w: Insegnamenti XXIV/2, 852; Do duchowieństwa w Damaszku w katedrze syryjskoprawosławnej 4 (6 V 2001), w: Insegnamenti XXIV/2, 901-902.

${ }^{2}$ Por. Encykliki: Dominum et Vivificantem 25, przypis 12 i nr 58, przypis 50; Redemptoris Mater 8, przypis 21; Solicitudo rei socialis 31, przypis 59; Adhortacje Apostolskie: Familiaris consortio 16, przypis 38; Redemptoris custos 1 i 8, przypis 4 i 21; Listy Apostolskie: Mulieris dignitatem 11, przypis 35; List Ojca Świętego Jana Pawła II: Do moich Braci i Sióstr - ludzi w podesztym wieku 4 (1 X 1999), przypis 8; Orientale lumen 10, przypis 27 i 28; Katechezy: Boskie natchnienie Pisma Świętego 3 (1 V 1985), przypis 5; Orędzia: Przebaczenie droga pokoju. Orędzie na Wielki Post 2001 r. 1 (7 I 2001), przypis 2. 
Tę część wystąpienia chcę podzielić na dwa punkty. W pierwszym zajmę się homilią poświęconą wprost Patriarsze Konstantynopola jako katechecie ${ }^{3}$. Dotyka ona obok kwestii związanych z głoszeniem Ewangelii, aspektu społecznego, tak wyraźnie znaczącego zarówno działalność pastoralną, jak i dydaktyczną Antiocheńskiego Kaznodziei. Jego wyczulenie na niesprawiedliwość w stosunkach społecznych, na biedę i nędzę wielu, bogactwo nielicznych, na odpowiedzialność wszystkich za dobre wykorzystanie darów ziemi jest do dziś przykładem ewangelicznego zaangażowania. W opracowaniu uwzględnimy także inne wypowiedzi Papieża odwołujące się do nauczania społecznego Patriarchy Konstantynopola. W drugiej części podejmiemy wspomnienie Antiocheńskiego Kaznodziei jako reprezentanta szeroko pojętej Tradycji Wschodu. Jako jeden z najczęściej wspominanych i przywoływanych Ojców Kościoła, natchniony komentator św. Pawła, obok Bazylego Wielkiego i Grzegorza z Nazjanzu wchodzący w skład Trzech Świadków Tradycji, w dokumentach papieskich jest przywoływany na potwierdzenie ortodoksyjnego charakteru wypowiedzi jak i jej zakorzenienia w Tradycji Kościoła niepodzielonego. Sformułowania Patriarchy Konstantynopola jako szczególnego rodzaju theologumena są tymi, które cieszą się autorytetem prawowierności ${ }^{4}$. Sw. Jan Chryzostom stał się sztandarowym świadkiem tradycji Kościoła w odniesieniu do wychowania dzieci i młodzieży w starożytności chrześcijańskiej i jako taki jest przywołany kilka razy w dokumentach papieskich. To zagadnienie omówimy pod koniec analizowania kwestii związanych z przywołaniem spuścizny Antiocheńczyka w nauczaniu Jana Pawła II.

1. Nauczyciel sprawiedliwości społecznej. Nawet dla postronnego obserwatora nauczania Jana Pawła II jest oczywiste, że kwestie społeczne to jedno z kluczowych zagadnień w działalności polskiego Papieża. Św. Jan Chryzostom jako człowiek, który swoją działalność kaznodziejską podporządkował, słowami papieża „urzeczywistnieniu sprawiedliwości” na wszystkich poziomach życia, jest idealnym wzorcem zaangażowania, które nie jest li tylko działalnością charytatywną, ale w pierwszym rzędzie świadectwem o Chrystusie. Jakie zatem elementy tego zaangażowania przywołuje Jan Paweł II i do jakich punktów nauczania Antiocheńczyka sięga?

Już lektura pierwszych fragmentów homilii przywołuje zaangażowanie patriarchy Konstantynopola oraz jako cechę charakterystyczną jego bezkompromisowość. Ewangelia ukazuje swoje piękno w prostocie, w jasności sądów i słowa. Tak musi znaczyć tak, nie znaczyć nie. Dla przekazu istotna jest ta

${ }^{3}$ Por. Homilia o św. Janie Chryzostomie wygtoszona w Moncton, Front Mountain Road (13 IX 1984) OsRom 124 (1984) nr 213, s. 1 i 4; przekład polski: OsRomPol 5 (1984) nr 9, s. 20-21; przedruk VoxP 10 (1990) z. 18, 45-53.

${ }^{4}$ Oczywiście, same sformułowania. Wnioski z nich wyciągane już nie mają tego autorytetu, choć oczywiście przywołanie tych autorów jako świadków wzmacnia zawsze moc dowodzenia. 
bezkompromisowość, bo ona gwarantuje dla odbiorcy, że usłyszane wezwania nie są tylko zadaniami dla niego, ale dla wszystkich i wynikają z logiki samych słów Chrystusa. Jak mówił Jan Paweł II:

„Św. Jan Chryzostom nie miał zamiaru w czymkolwiek łagodzić mocy i jasności Ewangelii i wymagań stawianych przez chrześcijański chrzest, Ewangelię, kapłaństwo, miłość i godność ludzi biednych"5.

Głosił, jak wzywał Apostoł Paweł, w porę i nie w porę. Nie zrażał się środowiskiem, które choć deklarowało się, jako pobożne i wierzące, to mimo wszystko nieobce mu były namiętności, intrygi, światowe życie i zamiłowanie do zbytku. Nawet groźba, nawet wygnanie nie wpłynęło na przekaz prawdy: „nie uląkł się niegodziwych sądów, nękania, oszczerstw, prześladowań”6. Ale ostrość stawianych kwestii, jasność sądu nie kłóciła się nigdy z miłością, wręcz odwrotnie, to miłość kazała stawiać sprawy na ostrzu noża. Jan Paweł II w swojej homilii wyakcentował ten aspekt działań Chryzostoma, ale można spokojnie powiedzieć - to miał wspólne z Patriarchą! Jego encyklika Veritatis splendor, jego wezwanie do sprawiedliwości społecznej, jego postawa wobec wszelkich działań uderzających w człowieka, pomimo opinii publicznej (jak, na przykład, kwestia ochrony życia, godności człowieka i sprzeciwu wobec cywilizacji śmierci i nieodpowiedzialnego seksu, nieuznawania wojny za sposób rozwiązywania problemów, sprzeciw wobec kary śmierci) to kontynuacja tego samego zdeterminowania charakterystycznego dla Antiocheńczyka.

Ale papieża w postawie Jana Chryzostoma interesuje nie tylko to bezkompromisowe głoszenie. Wydaje się, że akcent w analizowanej homilii jest położony na innym zagadnieniu. By głosić twarde słowa, potrzeba, aby miłość przeniknęła serce. Ta miłość musi mieć swoje korzenie w życiu łaski i ta miłość musi się ewangelicznie uzewnętrzniać. Miłość chrześcijańska musi być zakorzeniona w Bogu. Dlatego rozwija się i żyje tylko tam, gdzie człowiek otwiera się na działanie Boga poprzez modlitwę i sakramenty. Otwarcie na nie dokonuje się poprzez wiarę, bez wiary nie ma przystępu do $\mathrm{Boga}^{7}$.

Ale miłość to nie deklaracje. Miłość to życie, to zaangażowanie. O tym wymiarze przesłania Jana Chryzostoma przypomina Papież. Odwołuje się do znanego fragmentu z 50 Homilii do Mateusza:

„Chcesz uczcić Ciało Chrystusa? Nie gardź Nim, kiedy jest nagi. Nie czcij go tu, w Kościele, poprzez jedwabne tkaniny, podczas gdy na zewnątrz pozwalasz mu cierpieć z zimna i braku odzienia [...]. Bóg nie potrzebuje złotych kielichów, ale dusz ze złota" ${ }^{\prime}$.

${ }^{5}$ Homilia o świętym Janie Chryzostomie 2, VoxP 10 (1990) z. 18, 46.

6 Tamże 4, VoxP z. 18, s. 47.

${ }^{7}$ Por. tamże 6, VoxP z. 18, s. 48.

${ }^{8}$ In Matthaeum hom. 50, 3, PG 58, 508, por. tłum. A. Baron, ŹMT 23, 107-108. W tym samym kontekście pojawia się to zdanie podczas papieskiej audiencji w rocznicę wydania Rerum novarum 
Życie chrześcijanina jest więc troską o bliźniego, prawdą życia, gotowością do pojednania a nie ogranicza się do deklaracji czy kultu. Zaangażowanie społeczne w tym wypadku odgrywa pierwszorzędną rolę. Ono jest zawsze w służbie głoszenia Ewangelii.

Warto zauważyć, że podejmując tę kwestię w innym dokumencie - encyklice Solicitudo rei socialis, Jan Paweł II odnosząc się do wspomnianego stwierdzenia wyciągnął o wiele dalej idący wniosek:

„w całym nauczaniu i w najdawniejszej praktyce Kościoła zawiera się przekonanie, że z racji swego powołania jest on sam, jego szafarze i każdy z jego członków, zobowiązany do niesienia ulgi cierpiącym nędzę, bliskim czy dalekim, nie tylko $\mathrm{z}$ tego, co «zbywa», ale z tego, co jest konieczne do życia. W obliczu istniejących potrzeb nie wolno przedkładać nad nie bogatego wystroju świątyń i drogocennych paramentów przeznaczonych do kultu Bożego; przeciwnie, mogłoby się okazać konieczne sprzedanie tych dóbr, aby dać chleb, napój, odzież i dom temu, kto jest ich pozbawiony"9.

Jednakże odpowiedź na wyzwania życia społecznego, na troski kłopoty czy doświadczenia ludzi jest znakiem autentyczności wiary, a nie jednym z jej elementów. Nie wolno oderwać go od wiary, bo staje się filantropią i zabraknie duchowych korzeni, dających wysiłkom ludzkim sens i personalistyczny wymiar. Bez tego życia wiary nie ma spotkania z kimś, ale jest rozwiązywanie czegoś. Tak było za czasów św. Jana Chryzostoma, przypomina papież, tak jest we wspólnotach, do których kieruje swoje słowa. Prawda głoszenia to nie dźwięk i słowa, ale wejście w życie, w konkretnej sytuacji pomoc ludziom w warunkach kryzysu ekonomicznego związanego z przeobrażeniami konkretnej prowincji w Kanadzie, a związanymi ze zmianami globalnymi, w świecie gospodarki postindustrialnej. Bezrobocie i związane z tym frustracje wymagają odpowiedzi, a katecheza dla młodzieży, dla dorosłych czerpie swoją przekonywująca wartość z odwagi dostrzeżenia problemu, odwagi stanięcia przy potrzebującym człowieku, z pracy rąk i serc ludzi dobrej woli. Można dodać, że o tym samym przypominał Papież w Catechesi tradendae (nr 12) przywołując świadectwo Ambrożego i właśnie Jana Chryzostoma.

Leona XIII, gdzie Papież przypominał: „Jezus Chrystus, który tak bardzo nas umiłował, że oddał za nas swoje życie, i który daje się nam w Eucharystii jako chleb życia wiecznego, jest tym samym Chrystusem, który nas wzywa, abyśmy go dostrzegali w ciele i w życiu ubogich, On bowiem okazał pełną solidarność z nimi, zob. Co uczynicie Jemu, mnie uczynicie. Orędzie na Wielki Post 1991 2, w: Orędzia Ojca Świętego Jana Pawła II, II, Kraków 1998, 541-542. Ten fragment musiał być szczególnie ważny dla Jana Pawła II, bo odwołał się do niego kolejny raz przestrzegając wiernych przed zrytualizowaniem obchodów niedzieli. Eucharystia jest w centrum jako miłość, uczył papież, ale Eucharystia jako miłość, a nie tylko celebracja, por. Dies Domini 71.

9 Solicitudo rei socialis 31, w: Encykliki Ojca Świętego Jana Pawła II, Kraków 2006, 476. W przypisie do tego tekstu Jan Paweł II odwołuje się do przytoczonego przez nas wyżej fragmentu Homilii do Ewangelii Mateusza 50, 3-4, PG 58, 508-510. 
Ciekawe jest, z punktu widzenia analizy wystąpienia Papieża, odwołanie do jeszcze jednego elementu związanego z postacią św. Jana Chryzostoma. Jak wiadomo historykom, akcja charytatywna rozwinięta w Konstantynopolu przez Patriarchę, opierała się w większości na ludziach świeckich, grupach osób zaangażowanych, zgrupowanych w nieformalne struktury, złączonych jednym zadaniem i inspiracją Biskupa. Jan Paweł II przemawiał do katolików świeckich, zaangażowanych w życie społeczne, zgromadzonych w tak zwanych groupes - relais, które stanowiły strukturę równoległą do parafialnej. I choć papież podkreśla wagę jedności w działaniu, choć ukazuje parafię jako podstawowy element tego zaangażowania, docenia, dowartościowuje i uznaje rolę i autonomię tych grup będących indywidualną inicjatywą świeckich!

Podsumowując, w konkretnej sytuacji Jan Paweł II przywołał postać św. Jana Chryzostoma jako wzór człowieka wierzącego, który w zgodzie z sumieniem, bezkompromisowo głosi Ewangelię. Nie zapomina przy tym o miłości, a jego świadectwo jest potwierdzone osobistym zaangażowaniem na rzecz potrzebujących. To zaangażowanie i wyczulenie na ludzką biedę staje się zaczynem ewangelicznego zasiewu, który dzięki wierze, modlitwie i życiu sakramentalnemu jest wsparte łaską Boga. Dopiero taka katecheza staje się skutecznym narzędziem głoszenia Królestwa.

2. Reprezentant tradycji Wschodu. Jak już wspominaliśmy, dla chrześcijan Wschodu św. Jan Chryzostom jest jednym z uprzywilejowanych strażników tradycji. Odwołanie się do jego nauczania i przykładu w nauczaniu Jana Pawła II odgrywa ważną rolę we wzmocnieniu tego, co sam papież określił przywróceniem Kościołowi drugiego płuca. Tradycja szeroko rozumianego Wschodu jest, zdaniem Papieża jednym z integralnych elementów Tradycji całego Kościoła. Stąd stosunkowo częste odwołania do myśli Ojców Wschodu w dokumentach papieskich, pisanych z różnych okazji. Przykładem jest List Duodecimum saeculum z okazji 1200. rocznicy II Soboru w Nicei (787), gdzie papież mówiąc o Tradycji, której wyrazem jest Sobór i jego decyzje, przypomina odwołanie Ojców Soborowych do tradycji Ojców w wierze, wśród których wymienia, obok Bazylego Wielkiego, Grzegorza z Nyssy, Grzegorza z Nazjanzu, Cyryla Aleksandryjskiego, Jana Damasceńskiego także Jan Chryzostoma ${ }^{10}$.

Pneumatologia jest jednym z tych elementów Tradycji Wschodu, które w istotny sposób mogą ubogacić katolicką teologię. A jest to odwołanie do Tradycji żywej. Nic więc dziwnego, że u Papieża przyjmowanego przez wielu jako charyzmatyk ze Wschodu nauczanie dotyczące roli i działania Ducha Świętego w życiu wiernych odwołuje się także do tradycji św. Jana Chryzostoma. Widać to wprost w encyklice Dominum et Vivificantem, gdzie za Ojcami

${ }^{10}$ Por. Duodecimum saeculum 6, w: Listy Apostolskie Ojca Świętego Jana Pawła II, Kraków 2007, 264. 
całego Kościoła przypomina papież o szczególnym związku Ducha Świętego i Kościoła ${ }^{11}$. Związek ten jest porównywany do relacji dusza - ciało w człowieku. Obraz ten w szczególny sposób podkreśla jedność jak i to, że życiem i duszą wspólnoty wierzących jest działanie trzeciej osoby Boskiej. Dopełnieniem tej tajemnicy jest osobiste uświęcenie człowieka, który staje się świątynią Bożej obecności: , przez Ducha Świętego bowiem Ojciec i Syn przychodzą do niego [człowieka] i czynią u niego swe mieszkanie" $" 12$.

Źródłem życia dla teologii jest spotkanie z Pismem Świętym. Fenomenalna znajomość Pisma przez Jan Chryzostoma, jego zamieszkanie w tekście natchnionym i fascynacja słowem w Nim zawartym skłaniały Jana Pawła II do przywołania świadectwa Antiocheńskiego Kaznodziei, gdy omawiał boskie natchnienie Biblii. Tym bardziej, gdy było to świadectwo użyte przez Ojców Soboru Watykańskiego II. Dla św. Jana Chryzostoma:

„Słowa Boże, językami ludzkimi wyrażone, upodobniły się do mowy ludzkiej, jak niegdyś słowo Ojca Przedwiecznego, przyjąwszy słabe ludzkie ciało, upodobniło się do ludzi" 13 .

Ta typologia: Wcielenie - Pismo Święte była bliska zarówno jednemu jak i drugiemu, pozwalała z miłością i szacunkiem podejść do Biblii i odszukać w spotkaniu ze słowem w Piśmie miejsca na spotkanie ze Słowem Wcielonym w Eucharystii i w drugim człowieku. Szacunek do słowa dzięki obecności w nim Słowa - to coś, czego uczył Jan Chryzostom, co przypominał Papież.

Jednym z rysów pontyfikatu była głęboka maryjność Papieża. I tu Jan Paweł II odwoływał się do św. Jana Chryzostoma. Maryja - druga Ewa to przecież ulubione porównanie Ojców od Ireneusza z Lyonu, obecne także w homiliach Patriarchy Konstantynopola ${ }^{14}$. Nie obce jest mu także podkreślanie wyjątkowości darów łaski, jakie otrzymała Matka Pana, a świadectwo to jest szczególnie ważne tam, gdzie Maryja jest ukazywana jako wzór i jako Wspomożycielka $^{15}$. Ufne oddanie Maryi, papieskie Totus Tuus, bazuje na petni łask, którymi została napełniona pokorna Służebnica Pańska.

${ }^{11}$ Por. Dominum et Vivificantem 25, w: Encykliki Ojca Świętego Jana Pawła II, s. 282, przypis 96: S. Joannes Chrysostomus, In Epistolam ad Ephesios hom. 9, 3, PG 65, 72.

12 Dominum et Vivificantem 58, w: Encykliki Ojca Świętego Jana Pawła II, s. 333-334, przypis 254: S. Joannes Chrysostomus, In Epistolam ad Romanos hom. 13, 8, PG 60, 519, thum. T. Sinko: Św. Jan Chryzostom, Homilie na List św. Pawła do Rzymian, Kraków 1995, 208 (tekst w thumaczeniu polskim brzmi: „Nie może bowiem Chrystus nie być obecny, gdy Duch jest obecny. Gdzie jest obecna jedna osoba Trójcy, tam jest obecna cała Trójca, gdyż nie może się w sobie rozdzielać i zjednoczona jest jak najściślej).

${ }^{13}$ Katecheza o boskim natchnieniu Pisma Świętego 3 (1 V 1985), w: Katechezy Ojca Świętego Jana Pawła II - Bóg Ojciec, Kraków - Ząbki 1999, 42, przypis 4: Joannes Chrysostomus, In Genesim 3, 8, PG 53, 134.

14 Por. Mulieris dignitatem 11, w: Listy Apostolskie Ojca Świętego Jana Pawła II, s. 338, przypis 35: Joannes Chrysostomus, Expositiones in Psalmos 44, 7, PG 55, 193. 
Ubogacająca Kościół tradycja monastyczna ma swoje korzenie na Wschodzie, wśród Ojców Pustyni, w pismach Ojców Kościoła, którzy często mieli za sobą doświadczenie pustyni jak i życia monastycznego zarówno w formie anachoretyzmu jak i cenobityzmu. Jan Chryzostom w swojej młodości przeszedł przez samotnie, przez doświadczenie życia oddanego na wyłączną służbę Bogu. Podczas posługi duszpasterskiej zarówno w Antiochii, jak i w Konstantynopolu stykał się z mnichami, mówił o nich i do nich. Nic więc dziwnego, że odwołując się do wschodniej tradycji monastycznej Jan Paweł II sięgał także do interesującego nas Ojca. Jak mówił Jan Paweł II, św. Jan Chryzostom jest strażnikiem prawdy:

„W obliczu ogromu Bożego miłosierdzia mnichowi nie pozostaje nic innego, jak tylko głosić świadomość własnego radykalnego ubóstwa, które staje się jednocześnie błaganiem i okrzykiem radości z powodu zbawienia tym bardziej wspaniałomyślnego, ze nieosiągalnego z otchłani ludzkiej nędzy"16.

Ale aby wejść na szczyty, potrzeba taternika, alpinisty. Nikt nim się nie rodzi. Stąd w Kościele potrzeba wychowania. Grecka paideia do dziś stanowi wzór, jak można harmonijnie wychować człowieka i zaszczepić mu miłość do prawdy, która jest jedna. Każde umiłowanie prawdy otwiera więc człowieka na Boga. To wielka tradycja myśli Ojców, obecna w ich spotkaniu z kulturą helleńską. Do tego bogactwa odwołał się Jan Paweł II podczas pielgrzymki do Grecji. I tu świadkiem tradycji był św. Jan Chryzostom ${ }^{17}$. Wychowanie chrześcijanina to nie tylko kwestia wiedzy, mądrości, to także cnota, to praktyka życia. A chrześcijanin to człowiek, który musi mieć wpisane w życie gotowość do ryzyka i ofiar, bo taka jest logika Ewangelii. Zachęcając więc do podjęcia trudu przygotowań wielkopostnych w 2001 roku Papież odwołał się do słów Jana Chryzostoma:

„Wyrzeczenie się własnego «ja» jest trudne, ale możliwe, jeżeli będziemy liczyć na pomoc Bożą, udzielaną nam przez komunię z Osobą Chrystusa"18.

Jednak Patriarcha Konstantynopola to także jeden z pierwszych Ojców piszących o wychowaniu w rodzinie. Mówiąc więc o tym, słowami Antiocheńczyka,

15 Por. Redemptoris Mater 8, w: Encykliki Ojca Świętego Jana Pawta II, s. 363-364, przypis 21: Joannes Chrysostomus, In Annuntiationem, PG 62, 765-766.

16 Orientale lumen 10, w: Listy Apostolskie Ojca Świętego Jana Pawła II, s. 473, gdzie papież powołuje się na Chryzostomowe De conpunctione, PG 47, 391-422 oraz In Matthaeum hom. 15, 3, PG 57, 225-228, ŹMT 18, 175-177.

17 Por. Przemówienie wygłoszone podczas ceremonii powitania w Pałacu Prezydenckim w Atenach (4 V 2001) 4, w: Nauczanie Kościoła katolickiego, Kraków 2002, Wydawnictwo „M” (CD-ROM).

18 Orędzie na Wielki Post 2001 roku 5 (7 I 2001), w: Insegnamenti XXIV/1, s. 145, przypis 9: In Matthaeum hom. 65, 2, PG 58, 619-620, tłum. J. Krystyniacki, ŹMT 23, 280. 
„Kościele domowym”, papież przywołuje świadectwo Jana Chryzostoma traktującego to miejsce jako specyficzną przestrzeń działania i życia Jezusa pomiędzy ludźmi ${ }^{19}$. Takie podejście do tajemnicy rodziny każe Janowi Chryzostomowi, pomimo zachwytu towarzyszącego refleksji nad życiem monastycznym, docenić małżeństwo. W Familiaris consortio Antiocheńczyk będzie świadkiem szczególnego związku w godności jednego i drugiego powołania:
„Bardzo słusznie stwierdza św. Jan Chryzostom: «Kto potępia małżeństwo, po- zbawia także dziewictwo jego chwały, kto natomiast je chwali, czyni dziewictwo bardziej godnym podziwu i chwalebnym. To, co wydaje się dobrem tylko w po- równaniu ze złem, nie może być wielkim dobrem, ale to, co jest lepsze od tego, co wszyscy uważają za dobro, jest z pewnością dobrem w stopniu najwyżzzym»" 20 .

Ta wyjątkowa argumentacja, w wielkości i godności małżeństwa doszukująca się jednego z elementów świadczących o wyjątkowości i znaczeniu powołania monastycznego jest, porównując ją, na przykład, z Listami św. Hieronima, czymś wyjątkowym. Ale dla Papieża, który w swoim nauczaniu dowartościował małżeństwo i miłość małżonków także w jej aspekcie fizycznym świadek tradycji nie traktujący współżycia małżeńskiego jako czegoś wstydliwego i tylko tolerowanego, jest szczególnie cennym argumentem.

I wreszcie na koniec jedno. Przygotowując się do habilitacji zacząłem odkrywać św. Jana Chryzostoma, Teodora z Mopsuestii, św. Efrema, Teodoreta z Cyru jako przedstawicieli tradycji nie tyle greckiej, co specyficznej, własnej, syryjskiej, choć czasem mówiącej po grecku. Tak to widać w dzisiejszych studiach podkreślających syryjskie podłoże ich myślenia. Nie zdziwi więc słuchaczy radość, z jaką czytałem słowa Jana Pawła II witającego duchowieństwo w Damaszku:

„Tutaj, w Damaszku, pragnę złożyć hołd całej tradycji syryjskiej z jej bogatą jednością w różnorodności. Święci Paweł, Ignacy Antiocheński, Efrem, Jan Chryzostom, Szymon Słupnik, Jan Damasceński i wielu innych są dla nas świetlanymi nauczycielami. Widzimy w nich, że posłuszeństwo w wierze i cierpienie krzyża nigdy nie przestaną przynosić owoców zbawienia"21.

19 Orędzie na Światowy Dzień Modlitw o Powolania: Rodzina umacnia i ochrania Boży dar powołania 1 (26 XII 1993), w: Jan Paweł II, Dzieła zebrane, IV, Kraków 2007, 620-621.

${ }^{20}$ Familiaris consortio 16, w: Adhortacje Apostolskie Ojca Świętego Jana Pawła II, I, Kraków 2006, 111: Joannes Chrysostomus, De virginitate 10, PG 48, 540.

21 Przemówienie do duchowieństwa $i$ świeckich Kościołów prawosławnych i katolickich Syrii w katedrze syryjskoprawosławnej św. Jerzego w Damaszku 4 (6 V 2001), w: Insegnamenti XXIV/1, 901; Nauczanie Kościoła katolickiego, Kraków 2002, Wydawnictwo „M”(CD-ROM). 


\section{SAN GIOVANNI CRISOSTOMO NELL'INSEGNAMENTO \\ DI PAPA WOJTYŁA}

(Riassunto)

La letteratura patristica fu presente nell'interesse di Papa Wojtyła non soltanto come appoggio nell'insegnamento, ma sopratutto come modo alternativo per la dogmatica - scuola non speculativa ma storica. Questa dimensione é molto importante per Lui.

Si deve dire, in veritá, che Giovanni Paolo II nei suoi documenti raramente usava gli scritti di S. Giovanni Crisostomo. Ma queste citazioni sono molto significative. Grande Antiocheno é da Lui preferito quale testimone di caritá cristiana, solidarietá ed è anche uno dei primi Padri della Chiesa che ha valorizzato molto il matrimonio nei confronti della vita consacrata.

Il famoso vescovo di Costantinopoli era per Lui un catecheta speciale che con la vita ha testimoniato l'impegno sociale della Chiesa. Ma la figura di S. Giovanni Crisostomo é sempre nel quadro con gli altri grandi padri della Chiesa, testimoni di tradizione greca e siriaca del IV secolo nella Chiesa. Insieme con loro era presente nei momenti in cui il Papa voleva far vedere la continuitá dell'insegnamento della Chiesa su questi argomenti. Il modo di appoggiarsi sugli scritti di Grande Antiocheno é simile alla presenza degli altri padri nell'insegnamento di Giovanni Paolo II. 